International Research Journal of Management, IT \& Social Sciences
Available online at https://sloap.org/journals/index.php/irjmis/
Vol. 7 No. 1, January 2020, pages: 227-234
ISSN: 2395-7492
https://doi.org/10.21744/irjmis.v7n1.842

\title{
Benefits of Code-Switching in Language Learning Classroom at University of Education Lahore
}

Sidra Shafi

Syeda Hiraa Kazmi ${ }^{b}$

Rehman Asif ${ }^{c}$

Article history:

Submitted: 18 November 2019

Revised: 27 December 2019

Accepted: 14 January 2020

\section{Keywords:}

bilingual;

code-switching;

language;

learning process;

multilingual;

\begin{abstract}
Code-switching refers to the use of more than one language in a sentence or discourse. It is a natural commix that happens in utterances in bilingual and multilingual speakers reasoning one or more communal languages. Codeswitching (CS) denotes an alteration that is recorded between more than one variation in language following in the context of a single conversation. In sociolinguistics, code-switching is considered not merely one element of social life but encircles the social strata of speakers' social settings, linguistic variation and social variables. It is a linguistic strategy of bilingual or multilingual speakers. It is referred to as a "conversational scheme which is employed to constitute, cross or abolish group boundaries, to create, evoke or change interactive relation with their rights and commitments". (Gal, 1988). In multilingual contexts like Pakistan, code-switching is a common phenomenon. It appears as a conscious choice of language teachers to promote second language (L2) learning and improve second language comprehension among L2 learners. This article highlights the benefits of code-switching in the course of learning, explores some of the aspects of code-switching and its effectiveness in increasing L2 comprehension among the students at UE. It helped to illustrate the impact of code-switching to make classroom sessions interactive, to know the main causes of code-switching in communication and to know those triggering factors which forced students to switch from the native language (L1) to L2.
\end{abstract}

International research journal of management, IT and social sciences (C) 2020. This is an open access article under the CC BY-NC-ND license (https://creativecommons.org/licenses/by-nc-nd/4.0/).

\section{Corresponding author:}

Sidra Shafi,

Lahore College for Women University, Lahore, Pakistan.

Email address: seedrashafi@gmail.com

\footnotetext{
Lahore College for Women University, Lahore, Pakistan

University of Education, Lahore, Pakistan

${ }^{c}$ University of Management Sciences, Lahore, Pakistan
} 


\title{
1 Introduction
}

Pakistan is a multilingual country with more than sixty languages being spoken in its different parts, with Urdu standing as First Language (L1) and English as Second Language (L2). The majority of educational institutes in the country, particularly public sector institutes utilize a bilingual education system to facilitate students with diverse backgrounds. Teachers code switch to familiarize the students with foreign words and concepts pertaining to English language classes and also to various subject books written in English. Studies reveal code-switching as common phenomena in school, college and even university classrooms across the country. The University of Education is one such institute. With students coming from a different social stratum, it becomes an inevitable choice for teachers to code-switch so the lesson material related to English language learning may not appear too tiresome to students and they may easily grasp the foreign words, connotations, and concepts. The competency of English language learning only works to its maximum level once their essentials are met (Combs \& Ovando, 2012).

However, recent studies on bilingual Education receive hostility and discouragement regarding usage of codeswitching, considering it an ineffective practice (Ferguson, 2003), there are multiple types of research which analyze occurrence of code-switching in the classrooms in a natural way, considering all aspects of switching in course of instructing (Van de Walt et al., 2001). The positive features of code-switching include the capacity to make the target language more comprehensive, retaining students' attention, clarity of concepts, accessibility of target language and reinforcing lesson material. Adhering to these positive aspects of code-switching, this paper examines the benefits of code-switching in language learning classrooms of the University of Education, Lahore. How frequently English language teachers in the university code switch during instructions? Why they deem it necessary to do so? And what benefits they feel are associated with code-switching on the overall language learning process of students?

\section{Literature review}

\begin{abstract}
"Code-switching is the use of two or more languages in one speech exchange by bilingual or multilingual speakers... switches in language can occur between turns, within turns, and between constituents of single sentences (Bailey, 1999)".
\end{abstract}

Code-switching executes and accomplishes multiple without disturbing its occurrence in the original context. CodeSwitching has been employed by the speakers in order to operate or influence or delineate situation as want, and multiple layers of meaning and the subjective target was conveyed (Sert, 2005). It is observed that such speakers who have expertise in speaking more than one language or they are skilled in more than one range of any language, are more conscious of the fact that sometimes one variety works efficiently in the language comprehension in the specific context than the other (Meyerhoff, 2015).

Often, code-switching is used by bilinguals to swap from one language to the other, particularly when the usage of languages occur in the same setting, followed by functional and grammatical principles, and is a complex, rulegoverned phenomenon (Heredia \& Altarriba, 2001). It is an existing notion in the domain of multilingualism that the switching of code describes linguistic weaknesses or scantiness and it is hardly strived by many bilingual teachers who fight relentlessly in the situation to switch code in their classroom (Palmer D., Code-Switching and Symbolic Power in a Second-Grade Two-Way Classroom: A Teacher's Motivation System Gone Awry, 2009 as cited in Algarin-Ruiz, 2014). Factually, code-switching is all about an intellectual advantage than the conventional perspective of a deprived and semiliterate background (Hughes, Shaunessy, Brice, Ratliff, \& McHatton, 2006 as cited in Algarin-Ruiz, 2014). Regardless of the complexities involved in code-switching and the negative attitudes of educators towards its use in language learning classrooms, usually, code-switching is observed as a natural occurrence in language classrooms.

Modupeola (2013), talks extensively about why and how language teachers code-switch. He states, "Teachers employ code-switching strategy as a means of providing students with opportunities to communicate and enhance student's understanding. It further helps to facilitate the flow of classroom instruction since the teachers do not have to spend so much time trying to explain to the learners or search for the simplest words to clarify any confusion that may arise. The teacher uses code-switching by starting the lesson in the English Language and may move into the second language and back. This ensures that the lesson is as communicative as possible. This approach allows teachers to balance the use of language within a given contact. A teacher can exploit students' previous L1 learning experience to increase their understanding of L2." Modupeola's observation clearly indicates code-switching as a powerfully positive stratagem in language classrooms challenging the notion of those who believe code-switching to be a hurdle in the language learning process. Code-Switching could be utilized to have a command on content subjects that assist not only in teaching but also in cognitive learning too. Code-switching is a tool to aid teachers and students both, once the 
instructors are certain about the right usage and implementation of code-switching strategy in classrooms; that can be taken as linguistically proficient and fulfill their purpose what it is intended for, i.e. "enhancing teaching, learning and concept clarification" (Simasiku et al., 2015).

"Situation of code-switching in the classroom includes a topic switch, affective switch and repetitive switch" (Sert, 2005).

Code-switching may be employed to "announce specific identities, create certain meanings, and facilitate particular interpersonal relationships" (Johnson, 2000, as cited in Gudykunst, 2004). Code-switching includes modification of sentences, phrases from both languages and switching in a long narrative (Kasperczyk, 2005). According to Sert (2005), "this is mostly observed in grammar instruction, that the teacher shifts his language to the mother tongue of his students in dealing with particular grammar points, which are taught at the moment. It is also used by the teacher in order to build solidarity and intimate relations with the students".

L1 upholds that code-switching is not considered as a paucity in either of the languages involved; it is just a sheer distinctive property of bilinguals (as cited in Boztepe, 2002), Liebscher \& Dailey (2005), listed the significance of the classroom as a social zone for code-switchers to practice and it is a very integral part for bilinguals since different learning schemes for communication can be cultivated. Benson (2004), prefers bilingual education stating that codeswitching can actually help increase students' understanding of target language, provided that teachers utilize codeswitching in an effective and learning-friendly manner. She observes,

"Learning to read is most efficient when students know the language and can employ psycholinguistic guessing strategies; likewise, students can communicate through writing as soon as they understand the rules of the orthographic (or other written) system of their language. Use of their mother tongue to convey concepts and rules associated with target language exceeds their chances of grasping the full context and content of learning the second language”.

Aguirre (1988); Sadunih et al., (2018); Hudelson (1983); and Olmedo-Williams (1983), established Code-Switching as an operative teaching and communicative technique which is used preferably among bilingual learners. Ahmad \& Jusoff (2009), deduction exposed that beginners appreciate positively the usage of code-switching by teachers in English Language Teaching (as cited in Simasiku et al., 2015). Gulzar (2010), in his study about code-switching in bilingual classrooms of Pakistan, observes that code-switching in language classrooms is done to facilitate the students and students consider that teachers' code-switching actually helps them grasp the difficult ideas. He writes, "Codeswitching can cater to the need of the students. So it is strongly recommended that the use of code-switching as a strategy should be introduced for teaching English in the bilingual classroom discourse but keeping in view the level of the students. Teachers should not treat the use of CS by themselves or by learners as a sin, and CS has a place in ELT methodology if not used imprudently. Classroom code-switching is influenced by linguistic, psycholinguistic and social-situational dimensions... Spanish/ English students acquired lexicon expertise when the code is switched owing deficiency in vocabulary knowledge; this development happens when the student is given an awareness by explaining the meaning of the word code-switched in the other language (Becker 2000)".

Evidence gathered from the reviewed literature provided a sound base for the present study. It is apparent that despite the large body of research negating the usage of code-switching in language classrooms, numerous researchers, teachers, and students consider code-switching as an effective strategy for L2 learning. The key, however, is the effective and timely implementation of the strategy. Used in the right context, code-switching not only helps to comprehend foreign language but also improves students learning achievement. As Horasan (2014), puts it "teachers need to be aware of the fact that code-switching is for the development of the students' learning capabilities and should not be taken for granted. The use of code-switching in language classrooms does not show their competence or lack of competence in L2. Code-switching should rather be used as a tool that serves several functions that facilitate both learning and teaching."

\section{Materials and Methods}

The nature of the present study is descriptive. The data presented in this paper were collected during the ethnography of the communication case study (Bloom, 2008). The aim of linguistic ethnography is the study of both language and social life - and how the two intersect (Creese 2008). This particular methodology allowed the researchers to collect

Shafi, S., Kazmi, S. H., \& Asif, R. (2020). Benefits of code-switching in language learning classroom at University of Education Lahore. International Research Journal of Management, IT and Social Sciences, 7(1), 227-234. https://doi.org/10.21744/irjmis.v7n1.842 
qualitative data by asking questions to those involved in the field of language teaching to determine why language teachers code switch and do they really believe that code-switching is a helpful strategy in the complex scenario of L2 learning classrooms? Qualitative techniques permit scholars to discuss in lieu of the comprehension and perceptions of others and to discover how people learn about and make sense of themselves and others (Berg, 2001).

The population for the subject research is comprised of all language teachers in the University of Education's three campuses in the city of Lahore. By utilizing the Convenience Sampling technique sample is drawn from the population. Convenience sampling refers to a type of non-probability or nonrandom sampling wherein participants of the target population are shortlisted to meet the goal of the study, As in the case, if the particular standard is achieved, like geographical proximity, accessibility at a definite time, easy availability, or the inclination to volunteer (Dorneyi, 2007). "Captive audiences such as students in the researcher's" own institutions are primary examples of convenience sampling." (Dorneyi, 2007 as cited in Farrokhi \& Mahmoudi, 2012). Both the researchers according to their convenience selected the sample from Bank Road Campus of the University of Education where they work. 20 English instructors from the campus were nominated as participants for the study. Data was collected through a questionnaire with open-ended questions to allow the participants a reasonable scope to respond in a more beneficial way with a possibility to generate sufficient data with only a few questions.

\section{Results and Discussions}

Primarily the procedure of qualitative data analysis is a non-mathematical methodical process that comprises inspecting the connotation of people's words and actions (Morehouse \& Maykut, 2002). The data collected is analyzed descriptively. The descriptive method of data analysis is significant since it offers a very valuable analysis of the data (Tustin et al., 2010). The data collected and analyzed for the present study will be a valuable addition in the existing research on code-switching in English language learning classrooms in Pakistan. This article reduced the teacher's opinions about code-switching in language classrooms. The teacher's views about the benefits of code-switching were assessed by serving a questionnaire consisting of 10 questions. On each question, teachers responded accordingly and elaborated their view where required.

Table 1

Response to the first two questions mentioned

\begin{tabular}{ll}
\hline Sr \# & Questions \\
\hline 1 & How far is code-switching an automatic and unconscious behavior? \\
2 & Is the code-switching situation oriented? \\
3 & Does code-switching save time during language instruction? \\
4 & How far do you think is bilingual code-switching a useful teaching strategy? \\
5 & Does code-switching improve student's achievement in learning the language? If yes, how? \\
6 & Is code-switching beneficial only for students with low proficiency in the target language? \\
7 & Teachers mostly switch in L1 when students are unable to understand L2. What is your experience? \\
8 & Do speakers switch only when they feel hesitation or uneasiness in L2? \\
9 & How far code-switching facilitates the transference of linguistic and cognitive skills in students? \\
10 & How does code-switching strengthen the grammatical conceptual framework of students? \\
\hline
\end{tabular}

In response to the first two questions mentioned in table 1, 14 teachers strongly agreed that code-switching is an automatic and unconscious behavior and it is also a situation-oriented activity. One of the teacher responded, "Yes, I personally feel that when the situation demands, I mean when a student is unable to understand a concept in target language, I automatically switch to L1, If they will not understand a particular grammatical concept or a language formation rule, how can they be proficient in it? It is better to use code-switching strategy rather than leaving them confused and hesitant." This is similar to the findings that Macaro (2001), a case study discovered that teachers and students were interviewed and code-switched which was best explained in L1 of students when the comprehension level was distracted by the students and to mechanize the condition in case some difference in opinion arose.

17 teachers agreed on the point that code-switching is a time-saving activity whereas only 3 disagree. It indicates that students are not able to comprehend intricate concepts and notions if elucidated in the Target Language. By codeswitching, teachers save time using student's L1. The low-level learners had to verbally pose additional questions in 
the L1 to comprehend the assignment and consume time in resolving comparatively. The weak students remained confused when only TL is used in classrooms. As a participant shared, "Well, teaching in the target language does not take time... but comprehension... yes, that is another scenario altogether. If you teach students in the target language and explain the problematic area in a similar manner... that will surely take time. However, if we explain the problems in a language they are familiar with, it saves a lot of time because we have limited duration for language classes." Contra wise, the teachers also supposed that as the competency of students improves in the TL, the practice of codeswitching can be more restricted for better learning of L2. Findings from Bateman (2008), interviews also defined the motive behind using code-switching i.e. time constraint.

16 teachers commented that bilingual code-switching is a useful strategy, 4 appeared unknown of the usage of code-switching as a strategy. A similar response to Skolverket (2011) study emerged. Those who were in favor of code-switching as a useful stratagem said that the use of learners' mother tongue promotes student-teacher' codeswitching in the classroom and improves their intellectual abilities and understanding. Students must customize "language phenomena to clarify, vary and enrich communication", moreover, "they should use strategies to understand and be understood when language skills are lacking" (Skolverket, 2011).

The 18 teachers were of the view that code-switching improves student's achievement in learning the language. Suryasa et al. (2017), also underlined the implication of using students' L1 specifically with low proficiency students in the TL. However, the high proficiency students are always persistent and preferred that the lecture must be delivered in TL, although learners having inadequate capabilities in L2 direly required sustenance from the L1. The students believed that the target language is less supportive as compared to L1 for assistance in their language learning. Sometimes, it is problematic for the instructor to acclimatize the lecture as per the needs of all the students as for as the comprehension of bright and weak students are concerned. Skolverket (2001), also emphasizes that it is an obligatory right of every student to clear all courses and if any student is struck off and on the verge to be failed, the institution will facilitate the pupil to get through that course. The teachers at UE believed that code-switching is a huge help for students with low proficiency and as one of the teachers commented, 'the bright ones also don't mind it at all'. It is noteworthy for teachers to have ample knowledge about the students and their level of language capabilities. It will be helpful to comprehend as when and where it is should be employed for the maximum output from the students providing them a platform with the help of code-switching.

In response to question no 9 and 10, 17 teachers were of the view that the cognitive and linguistic competence is successfully reinforced in the language classrooms with the help of code-switching. They also believed that codeswitching triggers a better understanding of the grammatical rules of the target language. According to one participant, "There is no shame in admitting that our students fall shy when it comes to proficiency in a foreign language. With the use of L1 to transfer linguistics and grammatical prowess, they soon feel capable of handling L2 as well. The idea is to make them understand and able to use L2 as easily as L1. If code-switching can help in this regard, why not?" The use of code-switching should be handled carefully in language classrooms for pupils' level of comprehension. Being a useful strategy, L1 of students are utilized as an effective instrument for language learning. Inbar-Lourie (2010), draws attention that the use of L1 by teachers is discrete which depends on teachers' subjectivity and pedagogical philosophies. Cheng (2013), classroom reflection does not emphasis on teachers' individual beliefs and theories, however, the same inference has been established; as the instructions related to grammar have been imparted in pupils' L1. The teacher who hardly code-switched during a lesson focused on content, on the other hand when she orally explained grammar rules she did so in the students' L1.

\section{Conclusion}

The subject study has discussed teachers' usage of code-switching in language learning classrooms being found it an advantageous device for language teaching at UE. It illustrated that code-switching is a universal phenomenon. Codeswitching is preferred by teachers as an effective medium of teaching specifically in language classes. The results show that the teacher's positive attitudes towards code-switching have been consistently supported through all the data. The majority of the teachers opined that L1 smoothens the way of learning L2. The intricate linguistic concepts can be reinforced in class if code-switching is utilized. It is noteworthy to mention here that however monolingual teaching is preferred by instructors to improve acolyte's linguistic proficiency in English, they perceive code-switching as a course to strengthen their knowledge. The findings reflect that switching from L 2 to L1 does not have a negative impact on students' learning of L2. In language classrooms, code-switching is utilized as a language strategy that helps to facilitate conversation and keeping communication an ongoing process.

Shafi, S., Kazmi, S. H., \& Asif, R. (2020). Benefits of code-switching in language learning classroom at University of Education Lahore. International Research Journal of Management, IT and Social Sciences, 7(1), 227-234. https://doi.org/10.21744/irjmis.v7n1.842 
On the other hand, it can be proved as vital support to language development if used rightly. Hence, it is essential for language teachers to use code-switching when it is suitable for students' L2 and oral language development. De La Colina \& Pilar Garcia Mayo (2009), inspected the functions and operations of the usage code-switching in the oral interface of twelve low proficiency apprentices. The results showed that the technique of code-switching in language class concentrating on functions and uses of grammar and its form certainly paved the way for true learning for the students. It is deduced from the study that code-switching paves way for both teachers and students to complete the process of learning effectively. It not only is beneficial for the removal of uneasiness and hesitation to learn L 2 but also clarifies their basic and grammatical concepts. The teachers can save time using students' L1, like in paraphrasing, etc. Though, it is a point of high consideration that if students are facing utter difficulty to grasp the grammatical instructions and are not enough competent to comprehend L2, in that case, L1 can be utilized as a tool to the mechanic the situation. Those teachers who use code-switching are more popular and lovable for students that emphasize how influential and effective code-switching is and can be helpful in structuring the quality of teaching strategies and schemes in teaching to facilitate teachers.

\section{Conflict of interest statement}

The authors declared that they have no competing interests.

Statement of authorship

The authors have a responsibility for the conception and design of the study. The authors have approved the final article.

\section{Acknowledgments}

We are grateful to two anonymous reviewers for their valuable comments on the earlier version of this paper. 


\section{References}

Aguirre Jr, A. (1988). Code-Switching, Intuitive Knowledge, and the Bilingual Classroom.

Ahmad, B. H., \& Jusoff, K. (2009). Teachers' Code-Switching in Classroom Instructions for Low English Proficient Learners. English Language Teaching, 2(2), 49-55.

Algarin-Ruiz, K. M. (2014). Code switching: A tool in the classroom.

Bailey, S. J. (1999). Local government economics: principles and practice. Macmillan International Higher Education.

Bateman, J. (2008). Multimodality and genre: A foundation for the systematic analysis of multimodal documents. Springer.

Becker, H. J. (2000). Findings from the teaching, learning, and computing survey. Education policy analysis archives, 8, 51. https://doi.org/10.14507/epaa.v8n51.2000

Benson, C. (2004). Bilingual schooling in Mozambique and Bolivia: From experimentation to implementation. Language Policy, 3(1), 47-66. https://doi.org/10.1023/B:LPOL.0000017725.62093.66

Bloom, J. R. F. (2008). Pedagogic code-switching: A case study of the language practices of three bilingual content teachers (Doctoral dissertation, Teachers College, Columbia University).

Boztepe, E. (2003). Issues in code-switching: competing theories and models. Studies in Applied Linguistics and TESOL, 3(2).

Cheng, X. (2013). Research on Chinese College English Teachers' Classroom Code-switching: Beliefs and Attitudes. Journal of Language Teaching \& Research, 4(6).

Combs, M. C., \& Ovando, C. J. (2012). Chapter 1: Students. In bilingual and ESL classrooms: Teaching in multicultural contexts (pp. 6-46).

Creese, A. (2008). Linguistic Ethnography. Encyclopedia of Language and Education.

Dörnyei, Zoltán. "The L2 motivational self system." Motivation, language identity and the L2 self 36, no. 3 (2009): 911.

Farrokhi, F., \& Mahmoudi-Hamidabad, A. (2012). Rethinking Convenience Sampling: Defining Quality Criteria. Theory \& Practice in Language Studies, 2(4).

Ferguson, G. (2003). Classroom code-switching in post-colonial contexts: Functions, attitudes and policies. AILA review, 16(1), 38-51. https://doi.org/10.1075/aila.16.05fer

Gudykunst, W. B. (2004). Bridging differences: Effective intergroup communication. Sage.

Gulzar, M. A. (2010). Code-switching: Awareness about its utility in bilingual classrooms. Bulletin of Education and Research, 32(2), 23-44.

Heredia, R. R., \& Altarriba, J. (2001). Bilingual language mixing: Why do bilinguals code-switch?. Current Directions in Psychological Science, 10(5), 164-168. https://doi.org/10.1111\%2F1467-8721.00140

Horasan, S. (2014). Code-switching in EFL classrooms and the perceptions of the students and teachers. Dil ve Dilbilimi Çalışmaları Dergisi, 10(1), 31-45.

Hudelson, S. (1983). Beto at the sugar table: Code-switching in a bilingual classroom. Early childhood bilingual education: A Hispanic perspective, 31-49.

Inbar-Lourie, O. (2010). English only? The linguistic choices of teachers of young EFL learners. International Journal of Bilingualism, 14(3), 351-367. https://doi.org/10.1177\%2F1367006910367849

Johnson, A. G. (2000). The Blackwell dictionary of sociology: A user's guide to sociological language. WileyBlackwell.

Kasperczyk, L. (2005). Implementing code switching in the classroom. Retrieved May, 22, 2011.

L Berg, B. R. U. C. E. (2001). Qualitative research methods for the social sciences.

Liebscher, G., \& DAILEY-O'CAIN, J. E. N. N. I. F. E. R. (2005). Learner code-switching in the content-based foreign language classroom. The Modern Language Journal, 89(2), 234-247. https://doi.org/10.1111/j.15404781.2005.00277.x

Macaro, E. (2001). Analysing student teachers' codeswitching in foreign language classrooms: Theories and decision making. The Modern Language Journal, 85(4), 531-548. https://doi.org/10.1111/0026-7902.00124

Meyerhoff, M. (2015). Introducing sociolinguistics. Routledge.

Modupeola, O. R. (2013). Code-Switching as a teaching strategy: Implication for English Language teaching and learning in a multilingual society. IOSR Journal of Humanities and Social Science, 14(3), 92-94.

Morehouse, R. E., \& Maykut, P. (2002). Beginning qualitative research: A philosophical and practical guide. Routledge.

Olmedo-Williams, I. (1983). Spanish-English bilingual children as peer teachers. Spanish in the US setting: Beyond the Southwest, 89-106.

Shafi, S., Kazmi, S. H., \& Asif, R. (2020). Benefits of code-switching in language learning classroom at University of Education Lahore. International Research Journal of Management, IT and Social Sciences, 7(1), 227-234.

https://doi.org/10.21744/irjmis.v7n1.842 
Sadunih, S., Syahdan, S., \& Priyono, P. (2018). Code-switching by Members of Bilingual Families in Mataram. International Journal of Linguistics, Literature and Culture, 4(2), 81-88.

Sert, O. (2005). The Functions of Code-Switching in ELT Classrooms. Online Submission, 11(8).

Simasiku, L., Kasanda, C., \& Smit, T. (2015). Can Code Switching Enhance Learners' Academic Achievement?. English Language Teaching, 8(2), 70-77.

Skolverket. (2011). Curriculum for the compulsory school, preschool class and the recreation centre 2011.

Suryasa, W., Prayoga, I. G. P. A., \& Werdistira, I. (2017). An analysis of students motivation toward English learning as second language among students in Pritchard English academy (PEACE). International journal of social sciences and humanities, 1(2), 43-50. https://doi.org/10.29332/ijssh.v1n2.36

Tustin, D. H., Ligthelm, A. A., Martins, J. H. \& Van Wyk, H. De J. (2010). Marketing Research in Practice. 2nd Ed. Pretoria: Unisa Press.

Van de Walt, C., Mabule, D. R., \& De Beer, J. J. (2001). Letting the LI in by the back door: Codeswitching and translation in science, mathematics and biology classes. SAALT Journal, 35(2), 170-184. 